\title{
Studies on the Biochemical and Immunochemical Properties of Human Placental Lactogen (hPL: Human \\ Chorionic Somatomammotropin, hCS)
}

Part III Studies on Immunological Character and Its Clinical Application

\section{Hajime MORIKAWA}

Department of Obstetrics and Gynecology, Kobe University School of Medicine, Ikutaku,
Kobe 650, Japan (Director : Professor Shimpei Tojo, M.D.)

Purification and Biochemical character of hPL were already described (Folia Endocri. Japon., 49, 882 and 49, 1059, 1973).

In this paper, the author describes the immunological character of hPL and the method of the immunological measurement using its antigenecity. Anti-hPL serum was prepared by injecting purified hPL-Kobe with complete Freund's adjuvant into the male guinea pig or male rabbit, and had the specific titer to show cross reaction with $25 \mu \mathrm{g} / \mathrm{ml}$ hPL on Ouchterlony, but no cross reaction with human serum.

1. Immunological Character of HPL-Kobe

As reported, the biological action of hPL includes somatotropic or metabolic action (Sciarra et al., 1963, Tojo et al., 1972, Tanaka, 1972) and lactogenic or luteotrophic action (Ito \& Higashi, 1961, Josimovich et al., 1962). So the cross-reactivity of antihPL serum was investigated on Ouchterlony immunodiffusion against the human pituitary proteohormones, such as human growth hormone $(\mathrm{hGH})$ and human prolactin (hPRL), or the human chorionic such as human chorionic gonadotropin (hCG) and human chronic thyrotropin (hGT).

HPRL, hCG and hCT did not show the precipitation line against anti-hPL serum and a single line was observed against hGH which showed only a partial identity for hPL. On immunoelectrophoresis using anti-hGH serum, hGH and hPL showed a single precipitation line in agar gel and hGH migrate more rapidly to the cathode. These results reveal that hPL shares antigenic determinants not present in the other.

2. Immunoassay of HPL

For the estimation of human placental lactogen (hPL) three different immunoassay procedures, such as radioimmunoassay (RIA), single radial immunodiffusion (SRI) and hemagglutination inhibition reaction (HAIR) are reported here.

(1) HPL-Double Antibody Radioimmunoassay (HPL-RIA)

HPL-Kobe was used as the standard sample or the sample for iodination, and antisera to hPL was prepared in guinea pig against a purified hPL-Kobe. The iodination step presently used followed after the procedure described for growth hormone (Greenwood et al., 1963) with very minor modification. The reaction time of chloramin $\mathrm{T}$ 
was $15 \mathrm{sec}$. The dilution of anti-hPL serum was $1: 10000$, first incubation time was 48 hrs. and second incubation time was $24 \mathrm{hrs}$. The standard curve obtained was sensitive, and unlabelled hPL over $0.006 \mu \mathrm{g} / \mathrm{ml}$ was measurable. Using this method, serum $\mathrm{hPL}$ of the normal pregnant woman was measured, which revealed that hPL was detectable on the 8th week of gestation. The concentration was $0.03 \sim 0.01 \mu \mathrm{g} / \mathrm{ml}$. Thereafter, it rapidly increased to reach a peak of $4 \sim 10 \mu \mathrm{g} / \mathrm{ml}$ at term. A small amount of hPL was detectable in the cord blood and urine of the pregnant woman. Serum hPL was very low or undetectable in the abnormal pregnancy with hypofunction or dysfunction of placenta such as threatened abortion which terminated in abortion, ectopic pregnancy, fetal death in utero and hydatidiform mole. These facts indicate that measurement of serum hPL in the pregnant woman by hPL-RIA is one of the helpful ways to judge placental function.

(2) HPL-Single Radial Immunodiffusion (HPL-SRI)

The principle of SRI reported by Mancini et al. (1965) was applied to the measurement of hPL. The conditions of method were determined by easiness to read the precipitation ring and the area of the ring: anti-serum concentration in the agar plate, $1.0 \%$ : thickness of the plate, $1.2 \mathrm{~mm}$.: the diameter of the well, $4 \mathrm{~mm}$. HPL-Kobe as a standard sample was diluted at stepwise concentration and placed in the well. Three days later, the diameter of each precipitation ring formed a line with 5.48 of regression coefficient and the sensitivity was $5 \mu \mathrm{g} / \mathrm{ml}$. When serum hPL of normal pregnant women was measured simultaneously by hPL-SRI and hPL-RIA, the values measured by hPLSRI were 2-3 times higher than those by hPL-RIA. But normal ranges by both methods increased with identical pattern.

(3) HPL-Hemagglutination Inhibition Reaction (HPL-HAIR)

As serum was the sample to test in the measurement of hPL by HAIR, the effect of serum on hemagglutination was evaluated at first. Then, the sensitivity and reliability of this method were tested. Anti-hPL rabbit serum was used as antiserum, and sheep erythrocyte treated with formalin-tannic acid after Wide et al. was employed for hPLsensitized erythrocyte. The effect of serum protein on hamagglutination was negligible when serum of nonpregnant woman was diluted more than 20 times.

Five-hundred-time dilution of anti-hPL serum made it easiest to read the end point of the reaction. In other words, the sensitivity of this hPL-HAIR system was 0.1 $\mu \mathrm{g} / \mathrm{ml}$, and serum hPL is measurable if it is more than $2 \mu \mathrm{g} / \mathrm{ml}$. In this hPL-HAIR method, prozone phenomenon was not observed even when hPL concentration of serum was $1 \mathrm{mg} / \mathrm{ml}$, and moreover, $60000 \mathrm{IU} / \mathrm{ml}$ of serum hCG did not interfere with the reaction.

But, three of 18 nonpregnant women who were rheumatic showed a doubtful positive reaction. This is probably due to the fact that the rheumatic factor has a component to react with rabbit $\gamma$-globulin (anti-hPL serum). The sensitivity was elevated when hPL-HAIR was stored for two months at $45^{\circ} \mathrm{C}$, but it remained the same when stored for 6 months at $37^{\circ} \mathrm{G}$.

Vol. 50 No. 1 
So, this system was regarded as a very stable and reliable method. Measurement of serum hPL in 250 normal pregnant women by hPL-HAIR revealed that a constant value, $2 \mu \mathrm{g} / \mathrm{ml}$, was obtained at the 17 th week of gestation. And then it continued to increase until the 40 th week when the value was $6.5 \pm 1.1$ ( $\mathrm{M}_{ \pm}$S.D.). Values measured by hPLHAIR was somewhat higher than those by hPL-RIA from the same sample, but the patterns of normal range by both methods were almost identical. Summarizing the findings of the above three methods, hPL-RIA is the best method in its sensitivity $(0.006 \mu \mathrm{g} / \mathrm{ml})$, accuracy and specificity. But it sometimes takes much time before the measurement is really performed because of poor timing for sampling, and availability of isotope. HPLSRI is much less sensitive and specific than hPL-RIA, but measurement can be performed at any time, and the technique is simple. So, analysis of serial measurement may be helpful for the follow-up of the pregnancy course.

HPL-HAIR is useful for the measurement of hPL in clinical practice at late stage of pregnancy because of two advantages; the value almost corresponds to that of hPLRIA when it is over $2 \mu \mathrm{g} / \mathrm{ml}$; the time for procedure is the shortest, 2 hrs., among the three methods.

(See pp. 42 59) 


\section{ヒト胎盤ラクトーゲン (Human Placental Lactogen : hPL, Human Chorionic Somatomammotropin: hCS) の生化学的ならびに免疫学的性格にかんする研究} 第三編 hPL (hCS) の免疫学的性格とその臨床応用に関する研究

神戸大学医学部産科婦人科学教室（主任：東條伸平教授）

森川

hPL-Kobe は, Ouchterlony 法で hPRL, hGG (hG-LH) 及び hGT とは免疫交叉性を示さなかつ たが，hGH とは部分交叉性を示し，免疫電気泳動上 hGH よりやや陽極に泳動され，hPL と hGH は共通抗原を有すると考无れた。 hPL の蛋白体としての antigenecity を利用して, RIA, SRI 及び HAIR による hPL 測定法を考案したが，母体血中 hPL は，正常妊娠では妊娠初期から末期に向つて 増加する pattern を示し，一方胎盤機能の障害が疑われた症例では，きわめて低值であつた。

緒言

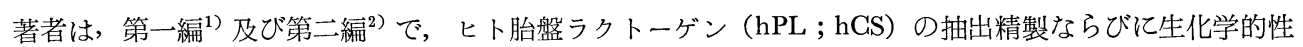
格を報告した. 本編では, まずhPL-Kobe の免疫学的性格を検討し，ついでその蛋白体としての antigenecity を利用して, hPL 測定法を工夫し, 弤娠個体における hPL の分泌動態を検討したので報告する.

\section{I . 研究の目的と計画}

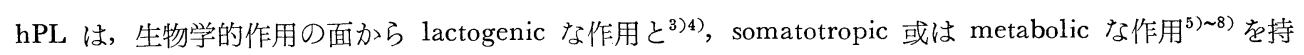
つととが明らかにされているので，乙のような作用を持つ下垂体性蛋白ホルモンのプロラクチン（hPRL), 及びヒト成長ホルモン $(\mathrm{hGH})$, さらには胎盤産生蛋白ホルモンのヒト絨毛性ゴナドトロピン (hCG) やヒ 卜絨毛性甲状腺刺激ホルモン (hCT) などとの免疫交叉性を，Ouchterlony 法 ${ }^{9)}$ ほり検討し，ついでその 抗血清を用いて hPL 測定法を考案し，臨床症例につき測定を行い，hPL の分泌動態を検討することとした。

\section{II. 実験材料と方法}

\section{A. 実験材料}

1.七ト胎盤ラクトーゲン (HPL ; HCS)

実験に用いた hPL は，著者が第一編 ${ }^{1)}$ 及び第二編 ${ }^{2)}$ で既述した hPL-Kobe である.

2 . ヒト成長ホルモン $(\mathrm{HGH})$

NPA の Dr. A.E. Wilhelmi より提供された hGH である.

3. ヒトプロラクチン (HPRL)

NIA, NIAMD の Dr. R.W. Bates から提供されたものである.

4. ヒト絨毛性ゴナドトロピン (HGG)

hCG は, 東條, 足高, 望月らにより, ヒト胎盤より抽出精製された hGG (hC-LH) を用いた ${ }^{10) 11)}$. 5.ヒト絨毛性甲状腺刺激ホルモン (HCT) 


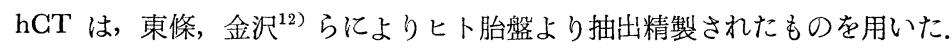

6. 抗 HPL 血清

i 抗 HPL モルモット血清

抗 hPL 血清は, hPL-Kobe をモルモットに反復投与して作製した。 ての抗 hPL 血清は, Ouchterlony 法 ${ }^{9)}$ そより, 標準 hPL の $25 \mu \mathrm{g} / \mathrm{ml}$ でも唯一の沈降線を示し，ヒト血清に対しては全く沈降線を示さなか つた ${ }^{13) \sim 15)}$.

ii 抗 HPL 家鬼血清

hPL-Kobe を雄成熟家鬼に反覆投与して作製した ${ }^{16)}$.

以上の抗血清は，いずれも血清分離直後に，56두゙ 30 分間インキュベートして非動化を行い，使用するま でー $20^{\circ} \mathrm{C}$ で涷結保存した。

7. 化学薬品

i BAGTO AGAR

DIFCO Laboratories (Detroit 1, Michigan, U.S.A.) のものを使用した.

ii Agarose

半井化学薬品株式会社製, 免疫電気泳動用のものを用いた.

iii リン酸緩衝液 $(\mathrm{PB})$

半井化学製品株式会社製試薬特級のリン酸一ナトリウム及びリン酸二ナトリウムを用いて, $\mathrm{pH} 7.5,0.05$

M PB 及び $\mathrm{pH} 7.5,0.5 \mathrm{M}$ PB を作成した.

iv Bovine Serum Albumin (BSA)

Armour Pharmaceutical Company (Chicago, Illinois, 60690, U.S.A.) のものを使用した.

$\mathrm{v}$ クロラミン T溶液

半井化学楽品株式会社製陚薬特級のものを使用し, $4 \mathrm{mg} / \mathrm{ml}$ の割合に $0.05 \mathrm{M}$ PB に溶解した.

vi メ夕重亜硫酸ナトリウム溶液

和光純薬株式会社製試薬特級のものを, $2.4 \mathrm{mg} / \mathrm{ml}$ の割合に $0.05 \mathrm{M}$ PB に溶解した.

vii ヨウ化カリウム溶液

和光純薬株式会社製試薬特級のるのを, $10 \mathrm{mg} / \mathrm{ml}$ の割合に $0.05 \mathrm{M}$ PB に溶解した.

viii $\mathrm{Na}{ }^{131} \mathrm{I}$

New England Nuclear Corporation (U.S.A.) の carrier free, 放射能純度 $99 \%$ で, $0.1 \%$ 苛性ソーダ溶 液に $530 \mathrm{mCi} / \mathrm{ml}$ 以上に濃縮されたものを使用した。

\section{B 実験方法}

1. HPL の免疫学的性格の検討

0.8\% DIFCO AGAR を用いた Ouchterlony double immunodiffusion 法9) そよつた.

寒天平板の中心孔には抗 hPL モルモット血清を, 周囲の小孔には hGH, hPRL, hGG (hG-LH)あるい は, hCT 溶液（それぞれ $1 \mathrm{mg} / \mathrm{ml}$ の濃度に溶解したもの）をそれぞれ注入し， $4{ }^{\circ} \mathrm{C}$ で24時間静置後, 各 々の免疫交叉性を検討した。対称の hPL-Kobe は, $100 \mu \mathrm{g} / \mathrm{ml}$ の濃度とした。

2. HPL 測定法の検討

血中 hPL 測定法は, 二抗体 radioimmunoassay, 一元平板免疫拡散法及び赤血球凝集阻止反応などの原 理を応用し, 工夫した。

i HPL Double Antibody Radioimmunoassay (HPL-RIA)

標準及び標識用 hPL は, hPL-Kobe であり, 抗血清は第一抗体に抗 hPL モルモット血清, 第二抗体に 抗モルモットケグロブリン家鬼血清を使用した。 Carrier protein は正常モルモット血清である。 また稀釈 用 buffer は， pH 8.6 ベロナール緩衝液に，0.5\% BSA，0.9\% NaCl を加えた溶液である。

a 抗原の標識と ${ }^{131} \mathrm{I} \cdot \mathrm{hPL}$ の精製 
ホルモンの標識は, Greenwood \& Hunter のクロラミン $\mathrm{T}$ 法 ${ }^{17) 18)}$ をやや改良して行なつた. 即ち $5 \mathrm{mGi}$ の $\mathrm{Na}{ }^{131} \mathrm{I}$ に, 正確に $\mathrm{pH} 7.5$ に調整された $0.5 \mathrm{M} \mathrm{PB}$ を $0.05 \mathrm{ml}$ 加え, $\mathrm{pH}$ を大体 8.5 亿調整した. 乙 れに hPL $10 \mu \mathrm{g} / 0.05 \mathrm{ml}$ を加えてよく混合し， クロラミン T 溶液 $0.05 \mathrm{ml}(200 \mu \mathrm{g})$ を加えよく混合した. クロラミン $\mathrm{T}$ の反応時間は, 正確に 5 秒, 15 秒, 30 秒間の 3 種とし, いずれの場合にも×タ重亜硫酸ナト リウム溶液 $0.2 \mathrm{ml}(240 \mu \mathrm{g})$ を加えて反応を停止させ， ヨウ化カリウム溶液 $0.8 \mathrm{ml}(8 \mathrm{mg})$ を加えた.

${ }^{131} \mathrm{I} \cdot \mathrm{hPL}$ と free ${ }^{131} \mathrm{I}$ の分離は，あらかじめ BSA で飽和した Sephadex G-75 カラム $(10 \times 250 \mathrm{~mm})$ に よるゲル沪過法によつた。

各溶出液の放射活性は, Aloka 製キューリーメーター IGG-1B, RIC-319 で測定した.

damaged ${ }^{131} \mathrm{I} \cdot \mathrm{hPL}$ の検討は，放射活性の最高の部位を Sephadex G-150 カラム $(10 \times 300 \mathrm{~mm})$ で refiltration することによつた.

b 抗 HPL 血清稀釈率の検討

2000，4000，6000，8000，10000，12000，16000，及び20000倍に稀勫した抗 hPL 血清のそれぞれ $0.5 \mathrm{ml}$ と ${ }^{131} \mathrm{I} \cdot \mathrm{hPL} 0.5 \mathrm{ml}\left({ }^{131} \mathrm{I} \cdot \mathrm{hPL}\right.$ として $\left.0.02 \mu \mathrm{g} / 0.5 \mathrm{ml}\right)$ を混合し， $4{ }^{\circ} \mathrm{C} て ゙ 48$ 時間インキュベーションしたあと， 第二抗体として抗モルモットケグロブリン家鬼血清稀勫液 $0.2 \mathrm{ml}$ を, carrier として50倍稀釈した正常モル モット血清 $0.2 \mathrm{ml}$ を加え， $4{ }^{\circ} \mathrm{C} ， 24$ 時間インキュベーションした．抗体 と結合した ${ }^{131} \mathrm{I} \cdot \mathrm{r} F \mathrm{~L}(\mathrm{~B})$ と結 合していない ${ }^{131} \mathrm{I} \cdot \mathrm{hPL}$ (F) の分離は, 反応終了液を $3000 \mathrm{rpm}$., 15分間遠沈し，上清を除去したあと，さ らに沈渣に稀釈用 buffer を $1 \mathrm{ml}$ 加え, 3000r.p.m. で再遠沈して行つた. 沈降率は, $\mathbf{B}+\mathrm{F}$ 及びBの放射 活性を well type の scintillation counter にて測定し， B + F に対するBの割合を百分率で表現した.

c Incubation time の検討

${ }^{131} \mathrm{I} \cdot \mathrm{hPL} 0.02 \mu \mathrm{g} / 0.5 \mathrm{ml}$ と 10000 倍稀釈した抗 $\mathrm{hPL}$ 血清 $0.5 \mathrm{ml}$ を混合し, incubation time を検討した。 まず first incubation time は，36，48，60，72時間の 4 種とし， second incubation time を24時間と一定 にして，それぞれの反応終了後のB＋Fに対するBの百分率から検討した．また second incubalion time は，fisst incubation time を48時間と一定にし， second incubation time を 12，18，24，30，36時間の5 種とし，それぞれの反応終了後の沈降率から検討した。

d 標準曲線の作成

${ }^{131} \mathrm{I} \cdot \mathrm{hPL} \quad 0.02 \mu \mathrm{g} / 0.5 \mathrm{ml}, 10000$ 倍稀釈抗 hPL 血清 $0.5 \mathrm{ml}$ 及び $0.005 \mu \mathrm{g} / \mathrm{ml}$ から $10 \mu \mathrm{g} / \mathrm{ml}$ の濃度に段階 稀釈した標準 hPL $1 \mathrm{ml}$ をそれぞれ混合し， first incubation time そ48時間， second incubation time を 24時間として反応させ，反応終了後，それぞれの沈降率を算出し，標準曲線を作成した。

e 実際の臨床症例の HPL 測定

神戸大学医学部附属病院を受診或は入院した正常及び異常妊娠妊婦及び新生児を対称とした.

正常妊娠 8 週から40週までの妊婦 200 例の肘静脈血を採取し，血清 hPL を測定した.

また正常妊娠 40 週の妊婦 5 例につき採尿し尿中 hPL を測定した.

さらに妊婦40週で正常分娩した新生児 5 例の臍帯静脈血を採取し，血清 hPL を測定した.

一方異常妊娠については，切迫流産 6 例（流産に終つたもの4例，弤娠を維持できたもの 2 例），子宮外 妊娠 4 例, 子宮内胎児死亡 4 例, 妊娠中毒症 7 例（うち 1 例は preeclampsia）, 胞状奇胎 6 例, の母体肘静 脈血を採取し，血清 hPL を測定した。

ii HPL Single Radial Immunodiffusion (HPL-SRI)

Mancini の報告した一元平板免疫拡散法による蛋白定量法を, 血清 hPL の測定に応用した.

a 寒天平板の作成

生理食塩水に 1.5\% Agarosc, 0.1\% $\mathrm{NaN}_{3}$ を加え, 温湯浴中で寒天が完全に溶けるまで加温する。

寒天が完全に溶けたら $56^{\circ} \mathrm{C}$ 恒温槽中に移し，10分以上経過後，抗 hPL 血清を加え泡をたてぬようによ く混和し，ガラス板上に流し寒天平板とする.

b 寒天内抗血清濃度の検討 
抗 $\mathrm{hPL}$ 家鬼血清の濃度を， $0.5 \%, 1.0 \%, 1.5 \%$ 及び $2.0 \%$ とし，それぞれ厚さ $1.2 \mathrm{~mm}$ ，抗原孔の 直径 $4 \mathrm{~mm}$ の寒天平板を作成した. $1 \mu \mathrm{g} / \mathrm{ml}$ 汃 $40 \mu \mathrm{g} / \mathrm{ml}$ まで段階稀釈した標準 hPL を, 各々の抗原孔 に $10 \mu 1$ ずつ注入し, 室温で 3 日間静置し, 沈降輪の面積を測定し, 標準回帰直線を作成した。

c 寒天平板の厚さの検討

抗血清濃度 $1.0 \%$, 抗原孔の直径 $4 \mathrm{~mm}$ とし, 寒天平板の厚さは $1.2 \mathrm{~mm}$ 及び $2.0 \mathrm{~mm}$ の 2 種を検討 した. $30 \mu \mathrm{g} / \mathrm{ml}$ の濃度の標準 hPL をそれぞれの抗原孔に注入し, 室温に 3 日間静置後の沈降輪の面積を測 定した.

d 抗原孔の検討

厚さ $1.2 \mathrm{~mm}$, 抗血清濃度 $1.0 \%$ とし, 抗原孔の直径を $3 \mathrm{~mm}, 4 \mathrm{~mm}$, 及び $5 \mathrm{~mm}$ とした寒天平板を 作成し， $1 \mu \mathrm{g} / \mathrm{ml}$ から $40 \mu \mathrm{g} / \mathrm{ml}$ まで段階稀䣋した標準 hPL をそれぞれの抗原孔に注入し，室温に 3 日間 静置後の沈降輪の面積を比較検討した。

e HPL-SRI による血清 HPL の測定

測定に用いた寒天平板は, 抗血清濃度 $1.0 \%$, 厚さ $1.2 \mathrm{~mm}$, 抗原孔の直径 $4 \mathrm{~mm}$ とし, $5 \mu \mathrm{g} / \mathrm{ml}$ から $40 \mu \mathrm{g} / \mathrm{ml}$ に段階稀䧽した標準 hPL を抗原孔に注入し, 標準回帰直線を作成した。

一方被検血清を同様に抗原孔に注入し, 生じた沈降輪の面積を標準回帰直線に照合し, 血清 hPL を測定 した.

正常妊娠例については, 妊娠 8 週から42週までの 100 例の弤婦血清を採取し, 血清 hPL を測定したが, そのうちの20例については hPL-RIA そより同時測定し，hPL-SRI と hPL-RIA そよる測定值を比較検討 した.

また正常分婏直後の新生児 5 例の臍帯血を採取し, 血清 hPL を測定した.

異常妊娠例については, 流産に終つた切迫流産 3 例, 子宮内胎児死亡 3 例, 妊娠中毒症 1 例, 無脳児妊娠 1 例, 胎盤機能不全 1 例の母体血清を採取し，血清 hPL を測定した.

iii HPL Hemagglutination Inhibition Reaction (HPL-HAIR)

HPL-HAIR により弤婦血中 hPL を測定するために，まず測定系に及ぼす血清蛋白体の影響を検討した あと，本系の感度の決定と安定性につき検討した。

a HPL-HAIR の作成

抗血清としては, 抗 hPL 家鬼血清を用い, hPL 感作赤血球は, Wide の方法 ${ }^{20)}$ によるルマリン, タ ンニン酸処理した羊赤血球を用いた。

本系による測定手技は，Table 1 の如くであり，反応終了時にアンプル底のリング形成を認めたものを， hPL 陽性とした。

Table 1. Testing procedures of hPL-HAIR

Ampoule A : diluted anti hPL serum (freeze-dried powder)

Ampoule B : hPL sensitized sheep erythrocytes (freeze-dried)

Ampoule $\mathrm{G}: 0.4 \mathrm{ml}$ of buffer solution

1. The test sample is reacted with the anti-hPL serum by adding $0.1 \mathrm{ml}$ of either standard hPL-Kobe or a suitable solution of the serum sample to ampoule A.

2. The buffer solution in ampoule $\mathbf{G}$ is added to ampoule $\mathbf{B}$ to make a suspension fluid of sensitized erythrocytes.

3. The hPL-sensitized erythrocyte suspension fluid in ampoule B is added to ampoule $\mathrm{A}$ and mixed thoroughly by shaking.

4. Ampoule $\mathrm{A}$ is then placed in a rack and left standing for 2 hours. 
稀釈用 buffer は， 0.1\% BSA を含さ pH 7.5 PB を, hPL free diluent は正常男子血清を, 稀釈用 buffer にて20倍に稀勫したものを用いた.

(1) 血球沈降像に及ぼす血清成分の影響にかんする検討

非妊婦血清を 1 1024 倍に稀釈したもの $0.1 \mathrm{ml}$ と hPL 感作赤血球浮遊液 $0.3 \mathrm{ml}$ を混合し, 円底小試験 管に入れ， 2 時間静置し，管底の血球沈降像を観察した。

(2) 抗 HPL 血清の稀釈倍数と正常ヒト血清の稀釈倍数の検討

非妊婦血清を 1〜30 倍に稀釈したもの $0.1 \mathrm{ml}$ と抗 hPL 血清を 100〜1000 倍に稀橎したもの $0.1 \mathrm{ml}$ の組 み合わせをそれぞれ作成し，それらに hPL 感作赤血球浮遊液 $0.3 \mathrm{ml}$ を加え，円底小試験管内でよく混和 し， 2 時間静置後の赤血球凝集反応による血球沈降像を観察した.

(3) 感度の検討

hPL free diluent に $0.05 \mu \mathrm{g} / \mathrm{ml} \sim 0.3 \mu \mathrm{g} / \mathrm{ml}$ の濃度に標準 $\mathrm{hPL}$ を溶解したものの各々の $0.1 \mathrm{ml}$ と, 400, 500 及び 600 倍稀粎した抗 hPL 血清の各々の $0.1 \mathrm{ml}$ とを混合し，それぞれの組み合わせに hPL 感作赤血 球浮遊液 $0.3 \mathrm{ml}$ を加えよく混和後, 2 時間静置し, 赤血球凝集阻止反応による血球沈降像から至適抗血清 濃度及び感度を決定した。

b プロゾーン現象の検討

標準 hPL を, $1 \mu \mathrm{g} / \mathrm{ml} \sim 50 \mu \mathrm{g} / \mathrm{ml}$ の濃度に, hPL free diluent そ溶解し，hPL-HAIR による 2 時間後 の血球沈降像を観察した.

\section{c 血中蛋白体の影響の検討}

妊婦血中に多量に存在する $\mathrm{hCG}$ とリウマチ因子につき検討した.

ヒト胎盤より抽出精製した hGG (hC-LH) を $1 \mathrm{IU} / \mathrm{ml}$ から $3000 \mathrm{IU} / \mathrm{ml}$ の濃度に hPL free diluent に 溶解し, hPL-HAIR による赤血球沈降像を観察した。

また RA test 陽性非妊婦18例の血清を20倍稀釈して, hPL-HAIR による赤血球沈降像を観察した。

d 本測定系の安定性にかんする検討

本測定系の安定性の検討は以下の如き方法によつた。

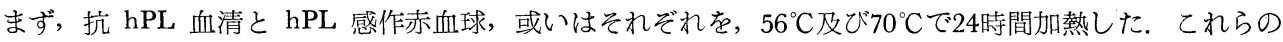
処理を行なつた測定系と段階稀釈した標準 hPL を用いて，赤血球凝集阻止反応を行ない，本系に及ぼす温 度の影響を検討した。

ついで抗 hPL 血清と hPL 感作赤血球を同時に，56ㄷ24，48及び72時間加熱したあと，段階稀勫した 標準 hPL を用いて，赤血球凝集阻止反応を行ない，加熱時間の影響を検討した.

また， $37^{\circ} \mathrm{C}$ 及び $45^{\circ} \mathrm{C}$ でそれぞれ，0 日，2 週間，1，2，3，4，5，6 ケ月間保存したあと段階稀勫 した hPL を用いて，赤血球凝集阻止反応を行ない，保存期間の影響を検討した。

e 妊婦血中 HPL の測定

正常妊娠例については, 妊娠 9 週から弤娠40週までの妊婦 250 例の血清を, また異常妊娠例については, 妊娠中毒症10例（うち preeclampsia 2 例），子宮内胎児死亡 3 例，切迫流産 1 例， Rh-sensitization 1 例， 糖尿病を合併したもの 2 例, 胞状奇胎 3 例の母体血清をそれぞれ利用した. それらの検討は，稀橎用 buffer により，20倍，40倍，60倍，80倍稀釈したあと，hPL-HAIR にて血清 hPL を測定した。 また若干例につ いては，hPL-RIA により同時测定を行ない，hPL-HAIR による測定值と比較検討した。

\section{C 実験成績}

1. HPL の免疫学的性格の検討

hPL と他の蛋白ホルモンとの免度学的交叉性を検討した成績は, Fig. 1 の如くである. 抗 hPL 血清に対して, hPL と hGH のみが, 明瞭な一本の沈降線を示し, 両者は部分交叉を示した.

2. HPL 測定法の検討

i . HPL Double Antibody Radioimmunoassay (HPL-RIA) 
Fig. 1. Immunoreactivity of hPL

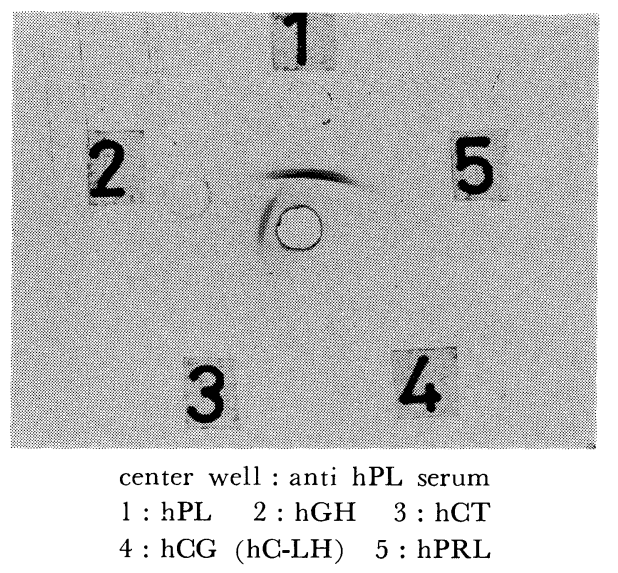

Fig. 2. Purification of ${ }^{131} \mathrm{I} \cdot \mathrm{hPL}$ on Sephadex G-75 gelfiltration : reaction time of chrolamin $\mathrm{T}, \quad 1: 5 \mathrm{sec} . \quad 2: 15 \mathrm{sec}$. $3: 30$ sec.

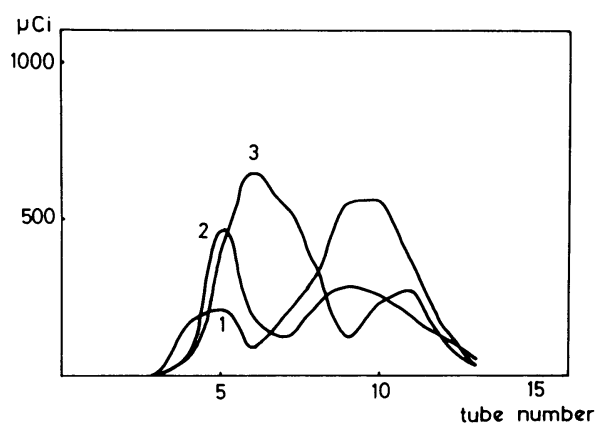

Fig. 3. Dilution of anti hPL serum

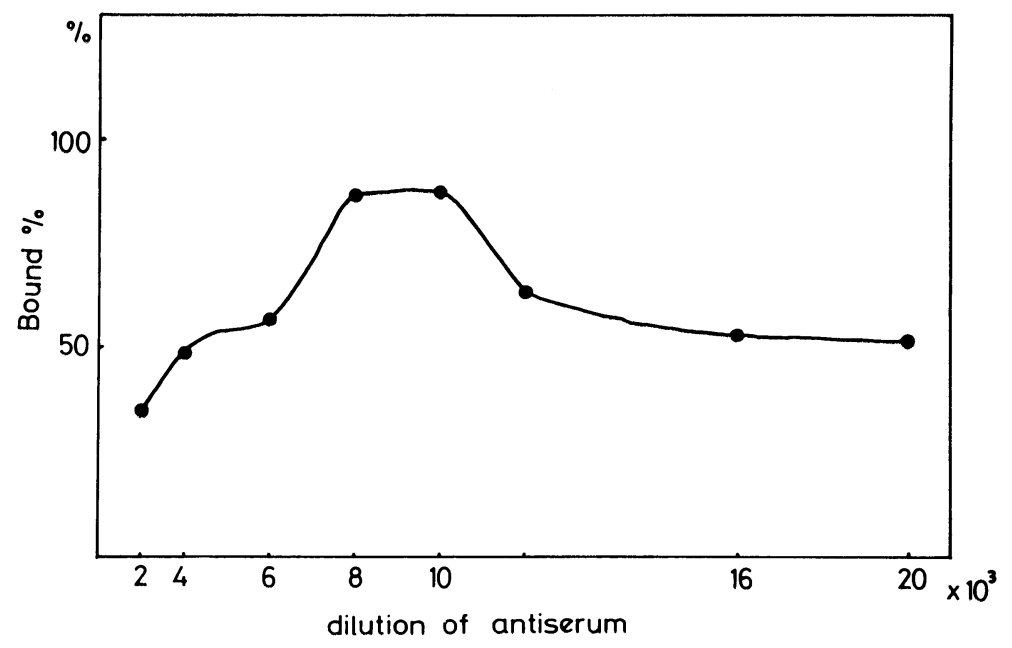

a 抗原の標識と ${ }^{131} \mathrm{I}-\mathrm{hPL}$ の精製

${ }^{131}$ I により hPL を標識して, Sephadex G-75 にて分離した成績を Fig. 2 に示す.

クロラミンTの反応時間が 5 秒間だと, ${ }^{131} \mathrm{I} \cdot \mathrm{hPL}$ peak (1) のはきわめて小さく, 30 秒間では, ${ }^{131} \mathrm{I} \cdot \mathrm{hPL}$ の peak (3) は二峰性を示す.

一方反応時間を 15 秒間とすると鋭い一峰性の ${ }^{131} \mathrm{I} \cdot \mathrm{hPL} の$ peak (2) が得られた。乙の peak で最も高い 放射活性を示した tube を, Sephadex G-150 で refiltration したところ，強い放射活性を示す均等な鋭い 一峰性の peak を示し，ホルモン標識の際に hPL の破壊がきわめて少ないことがわかる.

b 抗 HPL 血清稀釈率の検討

抗 hPL 血清を段階稀勫し，沈降率を検討した成績が Fig. 3 である. 沈降率は，抗 hPL 血清の稀釈が 8000〜10000倍で最高であつた.

c Incubation Time の検討

incubation time の検討成績は, Fig. 4 と Fig. 5 に示す. first incubatson time は48時間が, second 
Fig. 4. First incubation time of hPL-RIA

(second incubation time : 24hrs.)

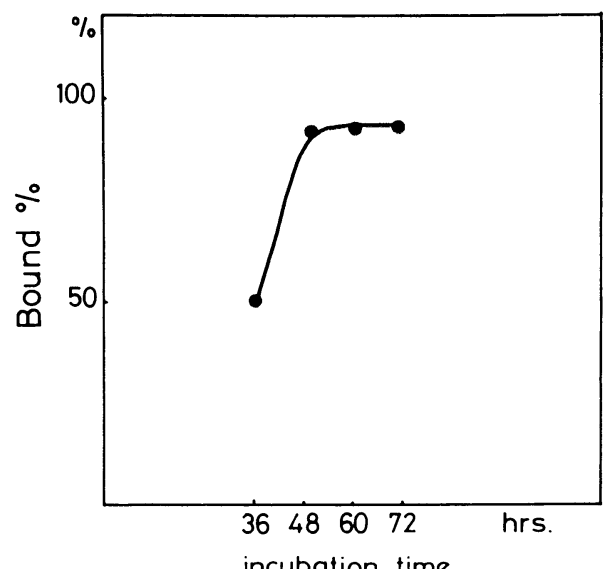

Fig. 5. Second incubation time of hPL-RIA (first incubation time : $48 \mathrm{hrs}$.)

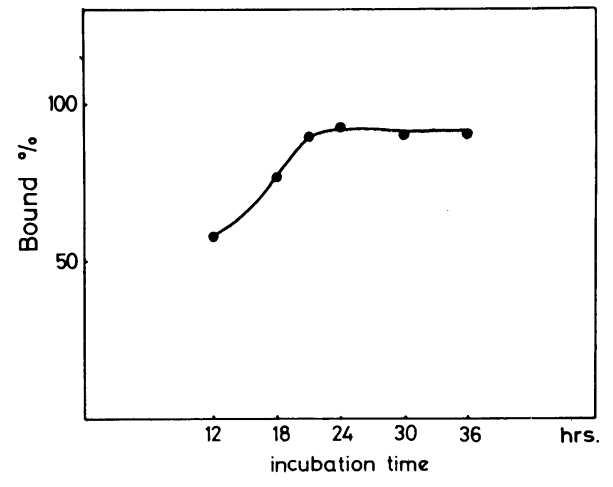

incubation time は24時間が適当であつた.

以上の成績から，hPL-RIA の測定手技を Fig. 6 のようにした。

d 標準曲線の作成

標準曲線は Fig. 7 の如くで, hPL 濃度 $0.006 \mu \mathrm{g} / \mathrm{ml}$ から $0.1 \mu \mathrm{g} / \mathrm{ml}$ の間で急峻な勾配を示した。

e 実際の臨床症例の hPL 測定

正常妊娠での母体血中 hPL を測定した成績を Fig. 8 亿示す. 母体血中 hPL は，妊娠 8 週から測定可能 で $0.01 \sim 0.03 \mu \mathrm{g} / \mathrm{ml}$ であるが，弤娠中期以後に急激な増加を示し，妊娠末期には $4 \sim 10 \mu \mathrm{g} / \mathrm{ml}$ となつた。

妊婦尿中 hPL は，0.2 0.6 $\mu \mathrm{g} / \mathrm{ml}$ と低值であつた。

また臍帯血中 hPL は，0.15〜 $0.45 \mu \mathrm{g} / \mathrm{ml}$ であつた。

Fig. 6. Assay system of hPL-RIA

\begin{tabular}{ll}
${ }^{131} \mathrm{IhPL}(0.04 \mu \mathrm{g} / \mathrm{ml})$ & $0.5 \mathrm{ml}$ \\
standard sample or serum sample & $1.0 \mathrm{ml}$ \\
anti hPL serum (first antibody) & $0.5 \mathrm{ml}$ \\
\hline first incubation $4^{\circ} \mathrm{C}, 48 \mathrm{hrs}$. & \\
\hline second antibody & $0.2 \mathrm{ml}$ \\
normal guinea pig serum $(1 \times 50$, carrier $) 0.2 \mathrm{ml}$ \\
$\downarrow$ second incubation $4^{\circ} \mathrm{C}, 24 \mathrm{hrs}$. \\
centrifugation $3000 \mathrm{rpm} ., 20 \mathrm{~min}$. \\
$\downarrow$ \\
sediment \\
$\downarrow$ \\
add $1.0 \mathrm{ml} 0.5 \mathrm{BSA}, 0.9 \% \mathrm{NaCl}, \mathrm{pH} 8.6$ \\
veronal buffer \\
$\downarrow$ \\
centrifugation $3000 \mathrm{rpm} ., 20 \mathrm{~min}$. \\
$\downarrow$ \\
sediment \\
$\downarrow$ \\
counting
\end{tabular}

Fig. 7. Standard curve of hPL-RIA

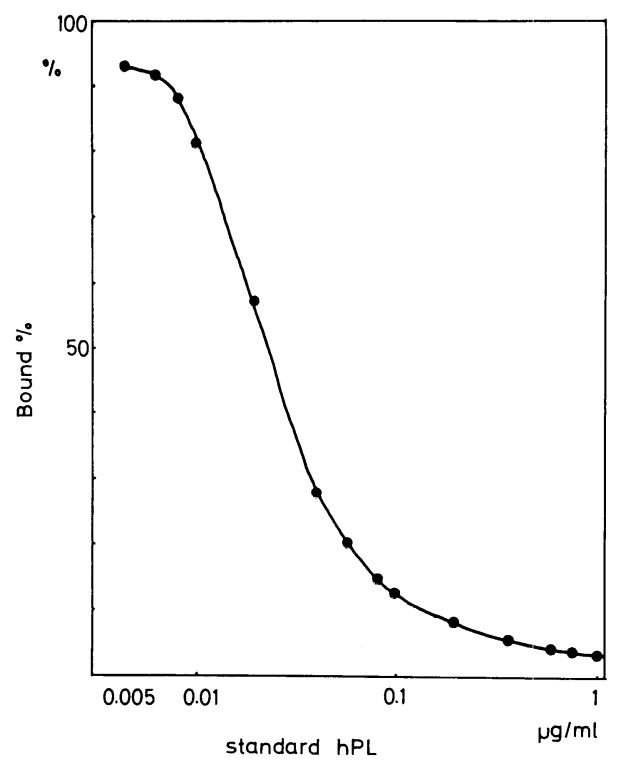


Fig. 8. Serum hPLin normal pregnancy (hPL-RIA)

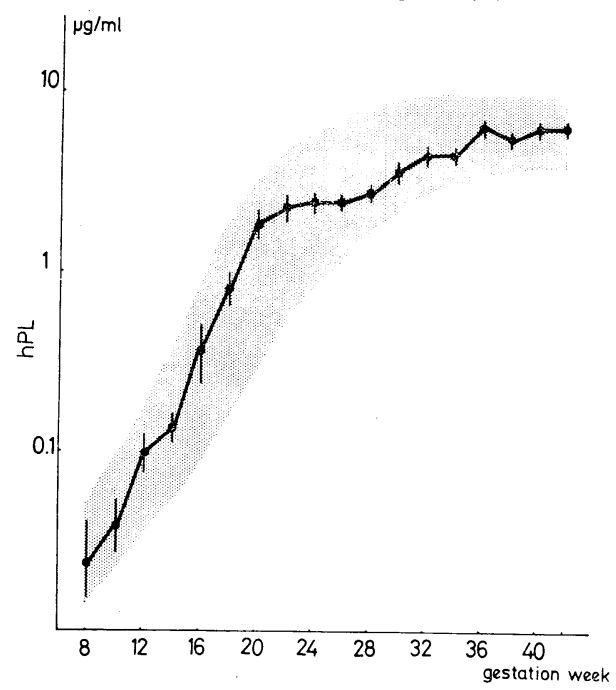

異常妊娠での母体血中 hPL 值は, Table 2 亿示 す如くである．切迫流産で，流産に終つた 4 例は， いずれも正常妊娠同時期の hPL 值上り低值を示し ているが，妊娠を維持できた 2 例はいずれも正常範 囲内にあつた。

子宮外妊娠の 4 例は，いずれも正常弤娠同時期の 值以下を示した．4例の子宮内胎児死亡例では，血 清 hPL は測定できなかつた.

preeclampsia を含む妊娠中毒症 7 例の血清 hPL 值は，いずれも正常範囲内にあつた。

胞状奇胎例は，全例きわめて低值であつた。

ii HPL Single Radial Immunodiffusion (HPLSRI)

\section{a 寒天内抗血清濃度の検討}

寒天平板内抗血清濃度を検討した成績を，Fig. 9

Table 2. Serum hPL in abnormal pregnancy (hPL-RIA)

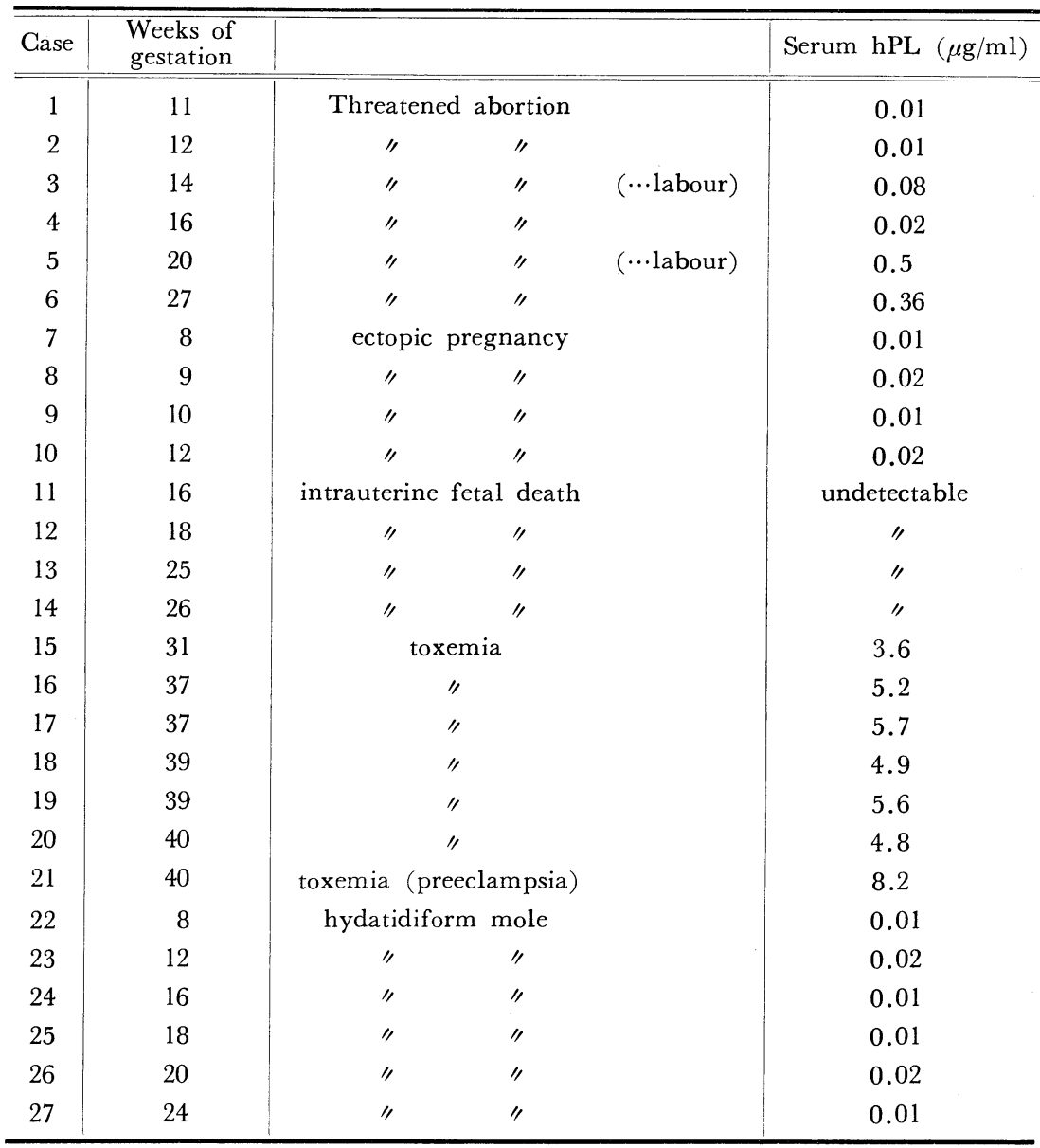


Fig. 9. A linear dose-response curve between the diameter of precipitation ring and the antigen concentration (hPL-SRI)

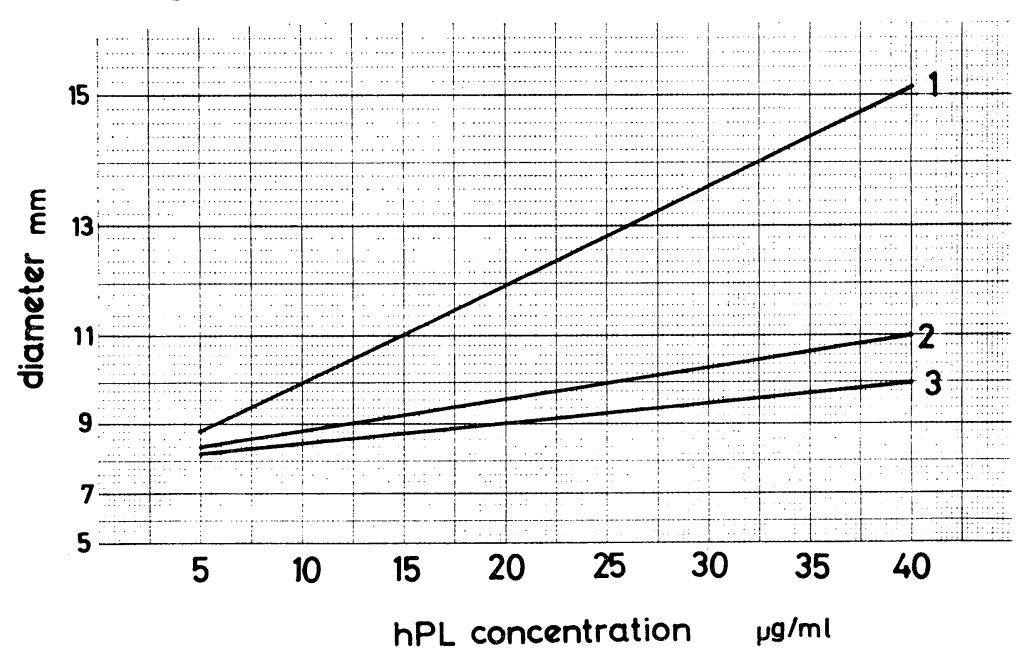

1 : anti hPL serum 1.0\% 2 : anti hPL serum $1.5 \% \quad 3:$ anti hPL serum $2.0 \%$

そ示す. 抗血清濃度が $0.5 \%$ は, 生じた沈降輪の面積は最大であつたが, 沈降輪の判読はきわめて困難で あつた.

$1.0,1.5$ と $2.0 \%$ では, 沈降輪の判読容易であり, 沈降輪の面積は $1.0 \%$ 最大で, regression coefficient は 5.48 であつた.

\section{b 寒天平板の厚さの検討}

厚さ $1.2 \mathrm{~mm}$ の寒天平板では沈降輪の直径は $11 \mathrm{~mm}$, 一方厚さ $2.0 \mathrm{~mm}$ では $9.6 \mathrm{~mm}$ であつて, 厚さ $1.2 \mathrm{~mm}$ の方が沈降輪の面積は大であつた。

\section{c 抗原孔の検討}

抗原孔の直径を，3，4，5 $\mathrm{mm}$ とした時の沈降輪の面積は， $5 \mathrm{~mm}$ の場合に最大で，ついで $4 \mathrm{~mm}, 3 \mathrm{~mm}$ の順であつたが, regression coefficient は, $3 \mathrm{~mm}$ の場合には 4.23, $4 \mathrm{~mm}$ の場合には $5.48,5 \mathrm{~mm}$ の場 合には 4.88 であり, 抗原孔の直径は $4 \mathrm{~mm}$ が最適であつた.

d HPL-SRI による血清 HPL の測定

作成した標準回帰直線から，hPL-SRI の測定感度は $5 \mu \mathrm{g} / \mathrm{ml}$ であつた. hPL-SRI による正常妊娠母体血 中 hPL は, Fig. 10 に示す如くであり，妊娠18週から測定可能で 5.0〜8.6 $\mu \mathrm{g} / \mathrm{ml}$ で，以後妊娠末期まで漸 増するパターンを示し，弤娠39週で peak となり 10-34 $\mu \mathrm{g} / \mathrm{ml}$ であつたが，弤娠 40 週から弤娠 42週にかけ 減少傾向を示した。

これらの検体のうちの 20例につき，hPL-SRI と hPL-RIA で同時測定を行なつた成績を Table 3 に示 す.hPL-RIA では，血清 hPL は妊娠 8 過から測定可能であつたが，hPL-SRI では，妊娠18週から測定 可能である。 また hPL-SRI そよる測定值は，hPL-RIA のそれに比し，かなり高值であつたしかし両測 定法による妊娠の経月的な測定值の増加傾向のパターンは，よく類似していた.

また臍帯血中 hPL は, hPL-SRI では測定できなかつた.

Table 4 は, hPL-SRI による異常妊娠例の測定成績である。切迫流産例のうち，2 例は血清 hPL の測 定が不能であり，1例は当初は，血清 $\mathrm{hPL}$ 值は $7.5 \mu \mathrm{g} / \mathrm{ml}$ と正常範囲内にあつたが, follow up 中に $5 \mu \mathrm{g} /$ $\mathrm{ml}$, undetectable と減少して流産に終つている. 子宮内胎児死亡例は, 全例血清 hPL は測定できなかつた。 
Fig. 10. Serum hPL in normal pregnancy (hPL-SR I)

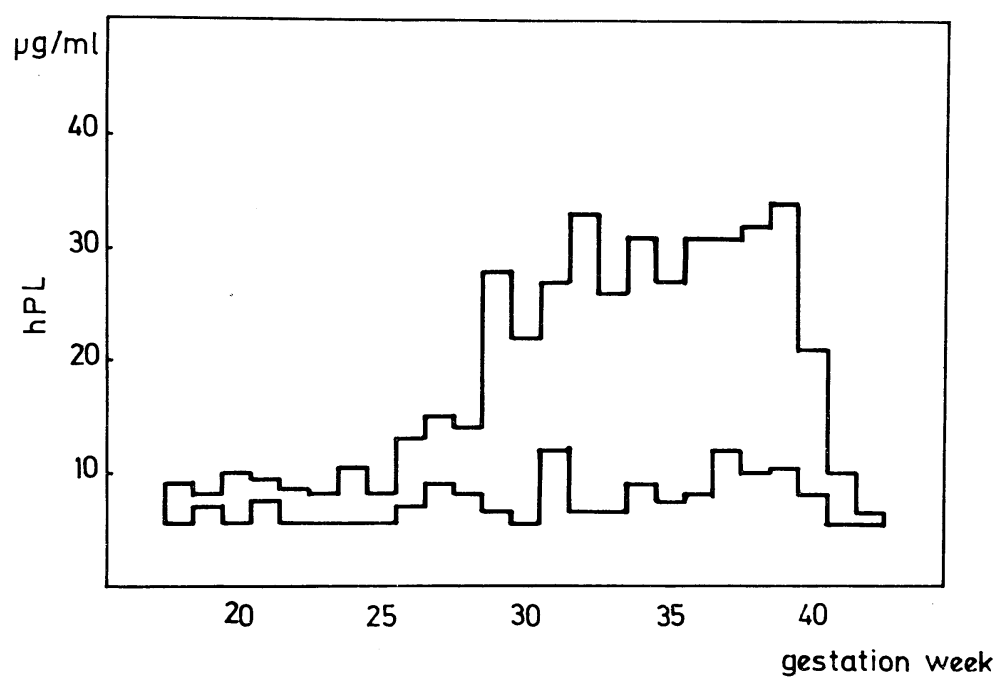

Table 3. Gomparison of serum hPL value simultaneouslv estimated by hPL-SRI and hPL-RIA.

\begin{tabular}{c|c|c|c}
\hline Case & $\begin{array}{c}\text { Weeks of } \\
\text { gestation }\end{array}$ & hPL-SRI $(\mu \mathrm{g} / \mathrm{ml})$ & hPL-RIA $(\mu \mathrm{g} / \mathrm{ml})$ \\
\hline \hline 1 & 8 & undetectable & 0.02 \\
2 & 10 & $\prime \prime$ & 0.68 \\
3 & 10 & $\prime \prime$ & 0.07 \\
4 & 15 & 8.2 & 4.0 \\
5 & 15 & 5.0 & 1.0 \\
6 & 18 & 10.2 & 2.0 \\
7 & 18 & 5.0 & 1.0 \\
8 & 20 & 5.0 & 1.0 \\
9 & 20 & 9.0 & 1.0 \\
10 & 25 & 22.5 & 2.0 \\
11 & 25 & 15.0 & 3.5 \\
12 & 28 & 18.5 & 6.2 \\
13 & 30 & 15.2 & 6.0 \\
14 & 32 & 19.5 & 6.5 \\
15 & 34 & 22.0 & 7.5 \\
16 & 36 & 19.5 & 8.2 \\
17 & 38 & 16.5 & 7.9 \\
18 & 40 & 19.2 & 8.3 \\
19 & 40 & & 4.2 \\
20 & 40 & & 8.2 \\
\hline
\end{tabular}

妊娠中毒症の 1 例（軽症型）は， $5 \mu \mathrm{g} / \mathrm{ml}$ で，正常妊娠娠同時期の下界よりも低值を示した。妊娠40週の無 脳児妊娠では，血清 hPL は $13.5 \mu \mathrm{g} / \mathrm{ml}$ と正常值であつた. 経週的な follow up ができた抗体産生 Rh 陰 性妊婦のケースでは, 妊娠29週から36週まで血清 hPL 值は増加し，以後やや減少したが，いずれも正常範 

Somatomammotropin : hCS) の生化学的ならびに免疫学的性格にかんする研究（森川）

Table 4. Serum hPL in abnormal pregnancy (hPL-SRI)

\begin{tabular}{|c|c|c|c|}
\hline Case & $\begin{array}{l}\text { Weeks of } \\
\text { gestation }\end{array}$ & & Serum hPL $(\mu \mathrm{g} / \mathrm{ml})$ \\
\hline 1 & 19 & Threatened abortion & undetectable \\
\hline \multirow[t]{2}{*}{2} & 20 & " " " & " \\
\hline & 19 & " " & 7.5 \\
\hline \multirow[t]{2}{*}{$3^{*}$} & $19+1$ day & & 5 \\
\hline & $19+2$ day & & undetectable \\
\hline 4 & 21 & intrauterine fetal death & " \\
\hline 5 & 32 & " " " & " \\
\hline 6 & 22 & " " " & " \\
\hline 7 & 40 & toxemia & 5 \\
\hline \multirow[t]{3}{*}{8} & 40 & anencephalus & 13.5 \\
\hline & 29 & Rh sensitization & 17.5 \\
\hline & 32 & & 20 \\
\hline \multirow{9}{*}{$9 *$} & 34 & & 21.5 \\
\hline & 36 & & 22.5 \\
\hline & 38 & & 15 \\
\hline & 40 & & 17 \\
\hline & 21 & placental insufficiency & 5 \\
\hline & 25 & & 7.5 \\
\hline & 27 & & 5 \\
\hline & 28 & & 7 \\
\hline & 32 & & 14 \\
\hline \multirow{5}{*}{$10^{*}$} & 34 & & 8 \\
\hline & 36 & & 7 \\
\hline & 38 & & 5.5 \\
\hline & 39 & & 5 \\
\hline & 40 & & 5 \\
\hline
\end{tabular}

* Estimations of hPL in case 3, 9 and 10 were performed serially.

田内での変動を示した，一方胎艋機能不全の症例の経週的な follow up では，妊娠中期の血清 hPL 值は， 正常範囲内にあつたが，後期から末期にかけては正常範囲以下の低值を示した。

iii HPL Hemagglutination Inhibition Reaction (HPL-HAIR)

a HPL-HAIR の作成

(1) 血球沈降像に及ぼす血清成分の影響にかんする検討

正常ヒト血清 1 ～ 8 倍の稀釈では, 血球球沈降像は不均一であつたが，16倍以上の稀釈では血球沈降像は 均一となり，血球沈降に及ぼす血清の影響は認められなくなつた。

(2) 抗 HPL 血清の稀勫倍数と正常ヒト血清の稀釈倍数の検討

非妊婦血清の 各種稀釈と抗 hPL 血清の各種稀勫の組み合わせを用いた赤血球凝集反応の成績を Fig. 11 に示す．非妊婦血清を15倍以上に稀釈すると，血清成分の赤血球凝集反応に及ぼす影響は認められなくなり， また抗 hPL 血清を 500 倍以上に稀釈すると正常な凝集反応が認められた。

(3) 感度の検討

最終的な抗 hPL 血清の稀釈率を赤血球凝集阻止反応で検討したところ, 抗 hPL 血清の稀釈は 500 倍が 最適であり，乙の時の反応系の感度は， $0.1 \mu \mathrm{g} / \mathrm{ml}$ (原血清中濃度として $2 \mu \mathrm{g} / \mathrm{ml}$ ) である. 
Fig. 11. Relationship between various dilutions of anti-hPL serum and various dilutions of normal human serum.

dilution of anti-hPL serum

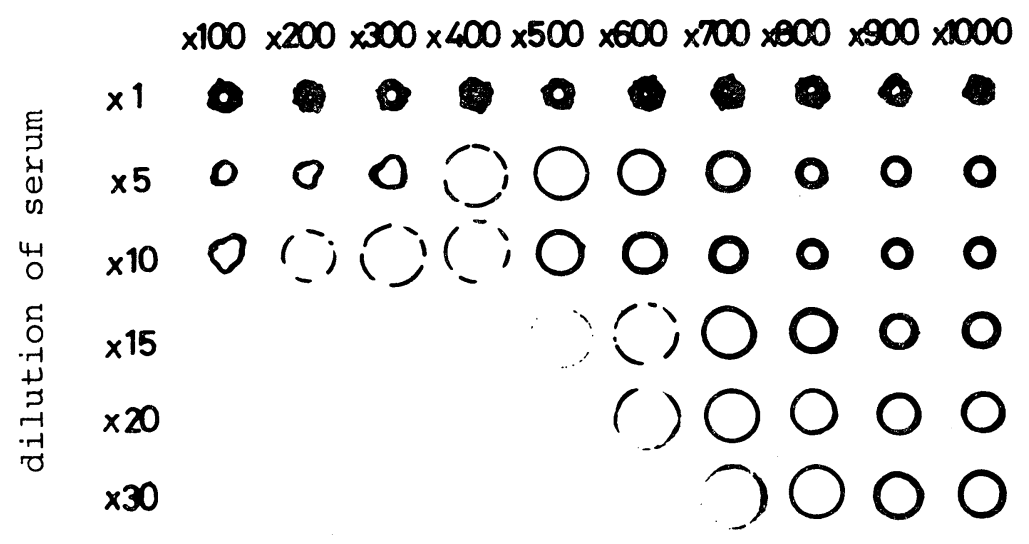

Aliquots of $0.1 \mathrm{ml}$ of various dilutions $(1-30 \mathrm{X})$ of nonpregnant serum and $0.1 \mathrm{ml}$ of various dilutions $(100-1000 \mathrm{X})$ of anti-hPL serum with $1 \%$ BSA solution were mixed with $0.3 \mathrm{ml}$ of the hPL-sensitized erythrocyte suspension fluid and the formation of the erythrocyte sedimentation ring produced by the hemagglutination reaction at the bottom of the ampoule was observed.

\section{b プロゾーン現象の検討}

$50 \mu \mathrm{g} / \mathrm{ml}$ （原血清中濃度として $1 \mathrm{mg} / \mathrm{ml}$ ）の高濃度の hPL が存在しても，赤血球凝集阻止反応に対する 抑制は起らなかつた。

c 血中蛋白体の影響の検討

$\mathrm{hCG}$ は $3000 \mathrm{IU} / \mathrm{ml}$ (原血清中濃度として $60000 \mathrm{IU} / \mathrm{ml}$ ) の濃度に存在しても反応感度に影響は認められな かつた。

リウマチ因子の存在する血清18例のうち，3例に偽陽性の反応を認めたが，他の15例の反応感度に変化は なく，陽性の反忍を示したものはなかつた。

d 本测定系の安定性にかんする検討

本系の安定性を検討した成績を Fig. 12，Fig. 13 亿示す. 本測定系を $56^{\circ} \mathrm{C} ， 24$ 時間加熱しても感度の変化

Fig. 12. Effect of temperature on stability of reaction reaction temperature $26^{\circ} \mathrm{C}$, reaction time $2 \mathrm{hrs}$.

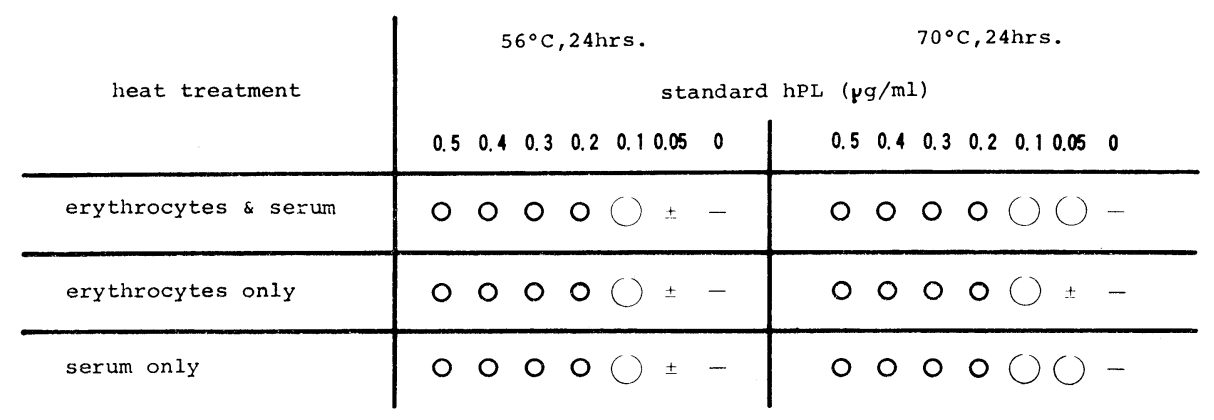


Fig. 13. Effect of storage period of hPL-HAIR on the test result.

\begin{tabular}{|c|c|c|c|c|c|c|c|c|c|c|c|c|c|c|c|c|c|c|c|c|}
\hline \multirow{2}{*}{$\begin{array}{r}\text { storage } \\
\text { period }\end{array}$} & \multicolumn{4}{|c|}{$\begin{array}{c}\text { standard hPI } \\
(\mu \mathrm{g} / \mathrm{ml})\end{array}$} & \multicolumn{6}{|c|}{$\mid \begin{array}{c}\text { nonpregnant } \\
\text { serum }\end{array}$} & \multicolumn{4}{|c|}{$\begin{array}{c}\text { standard hPL } \\
(\mu \mathrm{g} / \mathrm{ml})\end{array}$} & \multicolumn{6}{|c|}{$\begin{array}{c}\text { nonpregnant } \\
\text { serum }\end{array}$} \\
\hline & 0.2 & 0.1 & 0.05 & 0 & A & B & C & D & $E$ & $F$ & 0.2 & 0.1 & 0.05 & 0 & A & B & $C$ & D & $E$ & $F$. \\
\hline 0 & 0 & 0 & \pm & - & - & - & - & - & - & - & 0 & 0 & \pm & - & - & - & - & - & - & - \\
\hline $2 \mathrm{~W}$ & 0 & $\bigcirc$ & \pm & - & - & - & - & - & - & - & 0 & 0 & \pm & - & - & - & - & - & - & - \\
\hline $1 \mathrm{M}$ & 0 & 0 & \pm & - & - & - & - & - & - & - & 0 & 0 & \pm & - & - & - & - & - & - & - \\
\hline $2 \mathrm{M}$ & 0 & 0 & \pm & - & - & - & - & - & - & - & 0 & 0 & 0 & - & - & - & - & - & - & - \\
\hline $3 \mathrm{M}$ & 0 & 0 & \pm & - & - & - & - & - & - & - & 0 & 0 & 0 & \pm & - & \pm & - & \pm & - & - \\
\hline $4 \mathrm{M}$ & 0 & 0 & \pm & - & - & - & - & - & & - & & & & & & & & & & \\
\hline $5 M$ & 0 & 0 & \pm & $\therefore-$ & - & - & - & - & 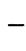 & - & & & & & & & & & & \\
\hline $6 \mathrm{M}$ & 0 & 0 & \pm & - & - & - & - & - & - & - & & & & & & & & & & \\
\hline & we & & & HON & & & & & & & & & empe & & ure & & $6^{\circ} \mathrm{C}$ & & & \\
\hline
\end{tabular}

Fig. 14. Graphic representation of measured values and standard deviations of hPL serum levels during normal pregnancy in 250 subjects.

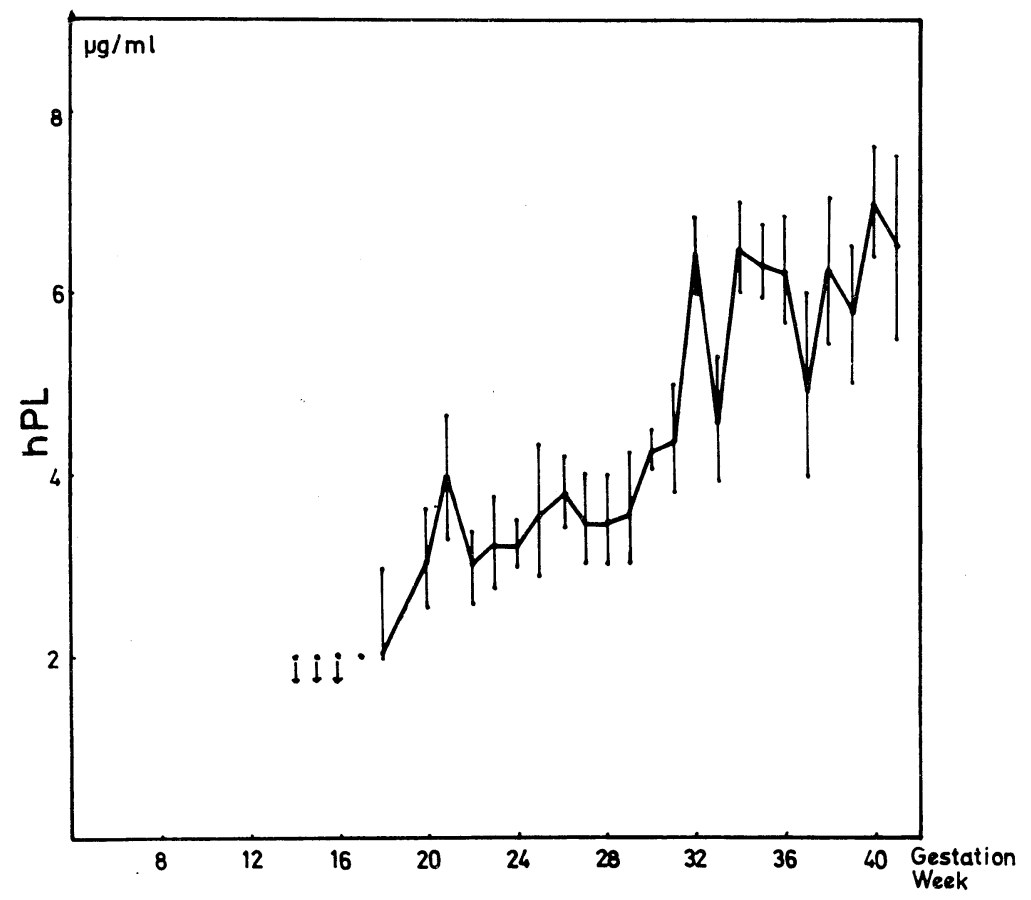

は認められなかつたが，抗血清あるいは抗血清と hPL 感作赤血球を70Cで24時間加熱すると, 本測定系の 反応感度が $0.05 \mu \mathrm{g} / \mathrm{ml}$ に上昇した。 また $56{ }^{\circ} \mathrm{C} て ゙$ 最高72時間まで加熱したが，感度に変化は認められなかつた。 


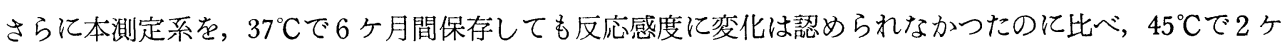
月間保存すると反応感度が $0.05 \mu \mathrm{g} / \mathrm{ml}$ と上昇し, また 3 ケ月間の保存では, 非妊婦血清に対して偽陽性の 反応が認められた。

e 妊婦血中 HPL の測定

正常妊娠 250 例の母体血清 hPL を測定した成績を Fig. 14 亿示す。妊娠17週から一定した測定成績が得 られ $2 \mu \mathrm{g} / \mathrm{ml}$ であり, 妊娠末期に向つて増加し, 弤娠 40 週では, $6.5 \pm 1.1 \mu \mathrm{g} / \mathrm{ml}$ であつた.

また 250 例のうちの 40 例につき, hPL-HAIR と hPL-RIA で同時測定を行なつた成績を Table 5 亿示 す. hPL-HAIR による測定值は hPL-RIA のそれに比し，やや高值を示すものの近似した值となつている. 異常妊娠例についての成績を Table 6 亿示す，弤娠中毒症では, いずれも正常範囲内の血清 hPL 值で あつたが, 子宮内胎児死亡の 3 例は全例測定不能であつた。切迫流産例は, 弤娠 27 週で $2 \mu \mathrm{g} / \mathrm{ml}$ と低值で, その後流産に終つた。妊娠 30 週, 抗体産生 $\mathrm{Rh}$ 陰性妊婦の血清 $\mathrm{hPL}$ は, $8 \mu \mathrm{g} / \mathrm{ml}$ と正常範囲よりやや高值 であつた，糖尿病を合併した 2 症例は, いずれも正常範囲内高值を示した。

胞状奇胎例の血清 hPL 值はいずれも測定不能であつた.

\section{III. 考按}

Human placental lactogen (hPL)の免疫学的性格についてはじめて報告したのは, Josimovich and MacLacen $(1962)^{4)}$ であつて，彼等は抗 hGH 血清を用いた実験で, hGH と retroplacental serum や胎盤抽

Table 5. Comparison of simultaneous determinations of serum hPL levels $(\mu \mathrm{g} / \mathrm{ml})$ with hPL-HAIR and hPL-RIA.

\begin{tabular}{|c|c|c|c|c|c|c|c|}
\hline \multicolumn{2}{|c|}{ Gestation } & \multicolumn{2}{|c|}{$\mathrm{hPL}$ concentration } & \multicolumn{2}{|c|}{ Gestation } & \multicolumn{2}{|c|}{ hPL concentration } \\
\hline Months & Weeks & RIA & HAIR & Months & Weeks & RIA & HAIR \\
\hline \multirow{5}{*}{3} & 9 & 0.08 & 0 & \multirow{5}{*}{7} & 25 & 2.2 & 4 \\
\hline & 10 & 0.09 & 0 & & 26 & 4.0 & 6 \\
\hline & 10 & 0.1 & 2 & & 26 & 4.0 & 4 \\
\hline & 11 & 0.8 & 0 & & 27 & 3.5 & 6 \\
\hline & 12 & 0.62 & 2 & & 28 & 3.0 & 4 \\
\hline \multirow{5}{*}{4} & 13 & 0.4 & 2 & \multirow{5}{*}{8} & 29 & 4.8 & 6 \\
\hline & 13 & 0.09 & 0 & & 30 & 4.5 & 4 \\
\hline & 14 & 0.1 & 2 & & 31 & 4.1 & 6 \\
\hline & 15 & 0.1 & 2 & & 32 & 4.2 & 8 \\
\hline & 16 & 0.1 & 2 & & 32 & 5.5 & 6 \\
\hline \multirow{5}{*}{5} & 17 & 0.1 & 2 & \multirow{5}{*}{9} & 33 & 3.3 & 4 \\
\hline & 17 & 0.7 & 2 & & 34 & 5.8 & 8 \\
\hline & 20 & 0.7 & 2 & & 36 & 6.8 & 8 \\
\hline & 20 & 1.0 & 2 & & 36 & 7.0 & 6 \\
\hline & 20 & 0.5 & 2 & & 36 & 6.5 & 8 \\
\hline \multirow{5}{*}{6} & 22 & 0.6 & 2 & \multirow{5}{*}{10} & 37 & 6.0 & 6 \\
\hline & 23 & 0.8 & 2 & & 38 & 4.5 & 6 \\
\hline & 24 & 3.0 & 4 & & 39 & 7.0 & 8 \\
\hline & 24 & 2.0 & 4 & & 40 & 5.4 & 8 \\
\hline & 24 & 2.0 & 4 & & 40 & 6.8 & 8 \\
\hline
\end{tabular}


ヒト胎盤ラクトーゲン (Human Placental Lactogne : hPL, Human Chorionic Somatomammotropin : hCS) の生化学的ならびに免疫学的性格にかんする研究（森川）

Table 6. Serum hPL levels in abnormal pregnancy and in pregnancy associated with other complications.

\begin{tabular}{c|c|c|c|c}
\hline Case & $\begin{array}{c}\text { Weeks of } \\
\text { gestation }\end{array}$ & Complication & RIA & HAIR \\
\hline 1 & 40 & toxemia (preeclampsia) & 8.2 & 8 \\
2 & 40 & toxemia & 4.8 & 4 \\
3 & 39 & toxemia & 7.5 & 8 \\
4 & 39 & toxemia & 5.6 & 6 \\
5 & 39 & toxemia & 4.9 & 4 \\
6 & 37 & toxemia & 5.7 & 6 \\
7 & 37 & toxemia & 5.2 & 4 \\
8 & 36 & toxemia (preeclampsia) & 7.2 & 8 \\
9 & 32 & toxemia & 5.0 & 4 \\
10 & 31 & toxemia & 3.6 & 0 \\
11 & 28 & intrauterine fetal death & 0.2 & 0 \\
12 & 20 & intrauterine fetal death & 0.96 & 0 \\
13 & 17 & intrauterine fetal death & 0.3 & 2 \\
14 & 27 & threatened abortion & 3.6 & 8 \\
15 & 30 & Rh sensitization & 5.5 & 8 \\
$16 *$ & 39 & diabetes mellitus & 8.2 & 8 \\
17 & 40 & diabetes mellitus & 8.6 & undetectable \\
18 & 16 & hydatidiform mole & 0.01 & undetectable \\
19 & 16 & hydatidiform mole & 0.01 & 0.02 \\
\hline$*$
\end{tabular}

* Estimations of hPL in case 16 were performed serially.

出物が免疫学的に部分交叉性を示すととを明らかにした．その後 Sciarra，Kaplan and Grumbach (1963) ${ }^{5}$ ， Friesen $(1965)^{21)}$, Florini et al. (1966) ${ }^{22)}$ などが同様の報告をしたが， hPL と hGH 以外の蛋白ホルモン との免疫交叉性を検討したものは少なく，わずかに Josimovich et al. (1963) ${ }^{22)}$ の hPL と sheep prolaction 㫫びに human chorionic gonadotropin (hGG) 及び Josimovich and Mintz (1968) ${ }^{24)} の \mathrm{hPL}$ monkey placental lactogen (mPL) 这びに monkey growth hormone $(\mathrm{mGH})$ の免疫交叉性の報告をみるのみで ある.

ところで，最近までの知見によれば，hPL は成長ホルモン様作用， lactogenic な作用， luteotrophic な 作用を持つと報告されており，そこで著者は，hPL とそれらの作用を示すヒト下垂体ならびにヒト胎盤産 生蛋白ホルモンとの免疫交皮性を検討した。

その結果, hPL は抗 hGH 血清に対し唯一本の沈降線のみを示し, hPL とは部分交叉であつたが, hPRL, hCG, hGT は抗 hPL 血清に対してなんら沈降線を示さなかつた.

また第一編に示したように，hPL は免疫電気泳動で抗 hGH 血清に対し一本の沈降線のみを示し，対称 の hGH よりやや陽極に泳動されている，つまり蛋白体としての hPL と hGH は，共通の免疫活性基を 有するが，全く同一のものではないと考えられる.

そこで，てのような hPL の antigenecity を利用して妊娠時のとのホルモンの動態を知るための測定法を 工夫した.

ところで蛋白ホルモンの微量測定法としては，現在 radioimmunoassay 法が盛んに用いられている.

この方法はきわめて微量の物質に関する抗原抗体反応を利用したものであるので, 標識及び標準用の純度 
の高いホルモンと特異性の強い抗血清を得るとと, ならびそ測定の手技を十分に検討して信頼度を高めるて とが要求される。著者が用いた hPL-Kobe は, 単一の蛋白体にまで精製されており, 抗 hPL 血清は標準 hPL $25 \mu \mathrm{g} / \mathrm{ml}$ に対して唯一本の沈降線を示す高い抗体価を持つたものである.

hPL の標識に際しては，既述した如くhPL が単純蛋白体で, しかも非常に不安定であるとてろから, 用いる $\mathrm{Na}{ }^{131} \mathrm{I} ，$ 標識反応の場の $\mathrm{pH}$ や蛋白質変性剤であるクロラミン $\mathrm{T}$ の反応時間などが重要な問題と なる。著者が用いた $\mathrm{Na}{ }^{131} \mathrm{I}$ は還元剤を含ま奴純度の高いものであり, 標識の場はほほ正確に $\mathrm{pH} 8.5$ とし ている.

またクロラミンTの反応時間を 30 秒間とすると, ${ }^{131} \mathrm{I} \cdot \mathrm{hPL}$ の比放射能は最も高くなつたが， ${ }^{131} \mathrm{I} ・ \mathrm{hPL} の$ peak は二峰性となり, hPL の破壊が起つていると考光られた。一方, 反応洔間を 15 秒間とすると, ${ }^{131} \mathrm{I} \cdot \mathrm{hPL}$ の peak は鋭い一峰性を示し, 比放射能は $100 \mu \mathrm{Ci} / \mu \mathrm{g}$ であつたが, Sephadex G-150 で refiltration を行 なつても鋭い一つの peak しか示さず, クロラミン T による hPL の破壊がきわめて少なく, 特異性の高 い ${ }^{131} \mathrm{I} \cdot \mathrm{hPL}$ が得られたと考えられる.

また抗 hPL 血清の稀釈率は, assay 系の感度を左右する最も重要な point であるが, 抗体の稀釈率が低 すぎても高すぎても，抗原との結合率が低く，抗 hPL 血清の稀䣋は，8000～10000倍が最適であつた。

抗体と結合した ${ }^{131} \mathrm{I} \cdot \mathrm{hPL}$ (B) と遊離の ${ }^{131} \mathrm{I} \cdot \mathrm{hPL}$ (F) の分離には, 二抗体法を用い第一反応時間は48時 間, 第二反応時間は 24 時間が最適であり, 反応終了後の B と F の分離には, buffer による洗條操作を加え て測定誤差を最少とした.

そこでてれらの特異性の高い抗原, 抗体を用いた, hPL radioimmunoassay 系で hPL-Kobe を標準品と して標準曲線を作成したところ, 標準 $\mathrm{hPL} 0.006 \mu \mathrm{g} / \mathrm{ml}$ から $0.1 \mu \mathrm{g} / \mathrm{ml}$ の間で急峻な勾配を示し, この測 定系はきわめて感度が高いととが明らかとなつた。

この hPL-radioimmunoassay (hPL-RIA) 系で, 正常弤娠 200 例の妊婦血清 hPL を測定したとところ, 妊娠 8 週ではじめて測定可能となり, $(0.01 \sim 0.03 \mu \mathrm{g} / \mathrm{ml})$, 胎盤が完成するといわれている妊娠中期から急速 に增加し，妊娠後期から末期に peak $(4 \sim 10 \mu \mathrm{g} / \mathrm{ml})$ となつた。 しかし臍带血中 hPL は $0.15 \sim 0.45 \mu \mathrm{g} / \mathrm{ml}$ と低值であり，hPL が胎児側へは移行していないか，移行しているとしてもでく微量であると考えられた。

また流産に終つた症例, 子宮外妊娠, 子宮内胎児死亡及び胞状奇胎例などの胎盤機能の低下又は廃絶が凝 われるものでは, 血清 hPL 值はきわめて低值が測定不能であつた。

これらのととから, hPL-RIA そよる妊婦血清 hPL の測定は, 妊娠経過の follow up の指標として, 特に胎盤機能検查法の一手段として有用であると思われる.

ところで, radioimmunoassay による hPL 測定法は精度, 感度, 特垬性が秀れ, 一度に大量のサンプル を測定できるが，特殊な装置，設備を要するとと，標識用 Isotope の入手時期, 標識ホルモンの保存などの 点で, ぞてでも, いつでも測定するというのには困難がある.

そこで, サンプルを採取後速やかて測定し, その結果をみながら, 経時的或いは経日的に臨床経過を追跡 するために，hPL 簡易測定法を工夫した。

一元平板免疫抗散法 (SRI) は, 抗体を含む寒天の薄屏に小孔をあけ, 乙こに抗原を入れて放射状に拢散 させ, 十分時間をかけて抗原を全て結合させると, 生した沈降輪の面積は抗原量飞比例し, 抗体濃度に逆比 例するととが， Mancini et al. ${ }^{19)}$ によつて報告されており，乙のSRI をhPL の測定に応用した。

しかし沈降輪の判読には, 寒天平板の厚さ, 寒天内抗血清浱度, 抗原孔の大きさ, 注入抗原量が影響を与 えると考えられ，まずそれらの条件を検討した。

寒天内抗血清濃度であるが，抗血清の稀䣋をうすくすると，測定感度はよくなるが，沈降輪の判読が困難 となるので, その濃度を $1.0 \%$ とした。一方その他の条件については, 沈降輪の濃淡よりむしろ抗原孔から の広がり具合を主な指標として検討し, 寒天平板の厚さ $1.2 \mathrm{~mm}$, 抗原孔の直径 $4 \mathrm{~mm}$, 注入量 $10 \mu \mathrm{l}$ と決 定した。この hPL-SRI を用いれば，検体を採取後72時間で血清 hPL 值を知ることができ，感度は標準 hPL-Kobe $5 \mu \mathrm{g} / \mathrm{ml}$ であつた. 
正常妊娠母体血清 hPL は, 妊娠 18 週から測定可能で $5 \sim 8 \mu \mathrm{g} / \mathrm{ml}$ であつたが, 以後漸増し, 妊娠末期には $10 \sim 33 \mu \mathrm{g} / \mathrm{ml}$ となり, 妊娠40週にはやや減少した. hPL-RIA と hPL-SRI で同時測定した成績を比較する と, hPL-SRI による測定值は, hPL-RIA のそれに比し $2 〜 3$ 倍高值となつたが，弤娠初期から末期にかけ て増加する正常值域のパターンは hPL-RIA のそれと類似していた. これらのととから, hPL-SRI は, 検 体を入手後すぐ血清 hPL を測定でき, 臨床症状に刘処できる利点があるが, 感度, 特異性の点で hPL-RIA そ劣り, one point の測定值よりむしろ連続測定によるパターンを分析した方がよいと考えられた.

そてで hPL-SRI の長所を改善した方法として, 赤血球凝集阻止反応による hPL 測定法を考案した.

hPL-HAIR は, 羊赤血球の沈降状態から hPL を測定する方法であり, 検体として用いる血清成分が測 定に大きな影響を及ぽすため検体の稀勫及び抗血清の稀釉に重要なポイントがある．著者の検討では，ヒ卜 血清を20倍以上稀釈すれば，血清による赤血球の沈降率に多少の変化はあるものの，hPL-anti hPL serum の反応をますます特異的にするてとができた。

抗 hPL 血清は, 抗体価の範囲内で稀橎する程, 微量の hPL が測定できる反面, あまり鋭敏にすると, 赤血球凝集阻止反応の end point が不明瞭になつたり, 再現性が悪くなつたりするため, 稀釉倍数を500倍 即ち感度を $0.1 \mu \mathrm{g} / \mathrm{ml}$ とした.

この hPL-HAIR 系では, 多量の hPL が存在してもプロゾーン現象は認められず, また hCG は 60000IU/ $\mathrm{ml}$ 存在しても赤血球沈降像に影響は認められず, わずかに RA test 陽性の血清のみが偽陽性の反応を示 した。

リウマチ因子は，Losspalluto ${ }^{25)}$ や Milgrom ${ }^{26)}$ が報告した如く，家鬼 グロブリンと反応する特質を持つた

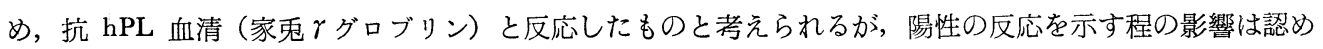
られなかつた。 また hPL-HAIR は, 抗 hPL 血清を凍結乾燥して保存するため, 保存条件により感度か変 化する可能性もあつたが， $37^{\circ} \mathrm{C} ， 6$ ケ月間保存しても安定であつた。 てれらのことから hPL-HAIR は血清 を採取後わずか 2 時間で hPL を測定でき, 感度, 特異性に秀れ, きわめて安定な測定系であるととが判明 した。 そてで hPL-HAIR を用いて正常妊娠母体血中 hPL を測定したとてろ, 妊娠17週より一定した測定 值が得られ，ての時期では $\mathrm{hPL}$ 值は $2 \mu \mathrm{g} / \mathrm{ml}$ であつたが，以後急増し，妊娠末期て peak _となり，4〜 $8 \mu \mathrm{g} /$ ml となつた. hPL-HAIR と hPL-RIA で同時測定した成績では, hPL-HAIR による測定值が，hPL-RIA のそれょりやや高值であり, 特に hPL 濃度が低い場合には, この傾向が強かつたが, 正常妊娠測定值域の パターンはきわめてよく一致した。 つまり血清 $\mathrm{hPL}$ 濃度が $2 \mu \mathrm{g} / \mathrm{ml}$ 以上の場合には, 特に妊娠後半期で は, hPL-HAIR の測定值はきわめて信頼度が高いことが判明した。

\section{結語}

1. Ouchterlony 法及び免疫電気泳動法により, hPL-Kobe の免疫学的性格を検討した.

hPL は, hPRL, hGG, hCT とは, 免疫交叉性を示さなかつたが, hGH とは部分交叉性を示し, 免疫電 気泳動上 $\mathrm{hGH}$ よりやや陽極に泳動され，hPL と hGH は共通抗原基を有するものの全く同一の物質では ないととが明らかとなつた。

2. radioimmunoassay 法, single radial immunodiffusion 法及び hemagglutination inhibition 反応な ぞの原理により, hPL 測定法を考案した, hPL-RIA は感度, 精度, 特異性の点で最も秀れた方法で, 感 度は $0.007 \mu \mathrm{g} / \mathrm{ml}$ であつたが, Isotope の入手の時期により検体採取後測定までに長時間を要するてとがあ り, 症例の follow up には retrospective になる色隃性がある. hPL-SRI は, 感度は $5 \mu \mathrm{g} / \mathrm{ml}$ で, かつ特 異性の点でも hPL-RIA 亿かなり劣るが, 誰でも, いつでも作製, 測定できる利点があり, 測定值のパタ 一ンの分析を行なえば, 妊娠経過を十分に追跡できる方法である. hPL-HAIR は, 感度が $2 \mu \mathrm{g} / \mathrm{ml}$ 以上で あるが, きわめて安定な測定系であり, 反応時間も 2 時間と短かく, 妊娠後半期の follow up では, hPLRIA ときわめて近似した值を示した。

稿を終るに臨み，終始御懇篤なる御指導と御校閲を賜つた恩師東條伸平教授に装心より感謝するとともに， 
直接御指導, 御鞭撻をいただいた望月真人講師及び曹洙鎔博士，平井至医学士をはじめとする教室の蛋白グ ループの諸兄姉に感謝します。また hGH 及び hPRL を提供していただいた NIH, NIAMD, Dr. R.W. Bates ならびに NPA の Dr. A.E. Wilhelmi に感謝します。また抗血清の作製にあたつて，ご助力いただ いた清水製薬甲賀博士，及び持田製薬小宮博士，小川博士に感謝します.

本論文の一部は第43回日本内分泌学会で報告した。

\section{参 考 文 献}

1）森川 肇: 日内泌誌, $49: 882$ (1973). Ito, Y. \& Higashi, K. : Endocri. Japon., 8 ; 2791961.

2) 森川 肇：日内泌誌, $49: 1059$ (1973).

J.A. : Endocrinology, $71: 209$ (1962).

Nature, Lond., 199 : 1005 (1963).

7) 村田孝美: 日内泌誌, $48: 6$ (1972).

Ouchterlony, O. : Acta Path. Microbiol. Scand., 32 : 231 (1953).
11) Ashitaka, Y, Mochizuki, M. and Tojo, S. : Endocri-

4) Josimovich, J.B. and MacLaren,

5) Sciarra, J.J., Kaplan, S.L. and Grumbach, M.M. :

6) 東條伸平, 望月真人：最新医学, $26: 1148$ (1971).

8) 田中歓子：日内泌誌, $48: 698$ (1972). et Gynaec. Jap., $17: 124$ (1970).

12）東條伸平, 金沢精一, 北垣壮之助, 望月真人：日内泌誌, $48: 364$ （1972）。 13）望月真人, 森川 肇, 水沢富一, 村田孝美, 椋田 亨, 東條伸平 : 臨床免疫, $2: 335$ （1970）。 14）東條伸平, 望月真人, 森川 肇, 水沢富一, 村田孝美, 椋田 亨, 岡部桂一郎, 曹 洙鎔：木と臨, $19: 283$ (1971). 15) Morikawa, H., Mochizuki, M. and Tojo, S. : Endocr. Japon., $18: 417$ (1971).

16）東條伸平, 望月真人, 森川 肇, 平井 至, 小川信久, 新海弘之, 小 雀浩司：産婦の世界, $25: 173$ (1973). 17) Greenwood, F.C.,Hunter, W.B. and Glover, W.B. and Glover, J.S. : Biochem. J., 89 : 114 (1963). 18) Hunter, W.M. and Greenwood, F.C. :

Biochem. J., 91 : 43 (1964). nochem., $2: 235$ (1965).

19) Mancini, G., Carbonara, A.O. and Heremans, J.F. : Immu21) Friesen, H. : Endocrinology, $76: 369$ (1965). 20) Wide, L. and Gemzell, G.A. : Acta Endocrinol., $35: 261$ (1960). Coppola, J., Ringler, I. and Bell, P.H. : Endocrinology,79 : 692 (1966). Atwood, B.L. and Goss, D.A. : Endocrinology, $73: 410$ (1963). Mintz, D.H. : Ann. N.Y. Acad. Sci., 148 : 488 (1968). 22) Florini, J.R., Tonelli, G., Breuer, G.B., $110: 169$ (1959). 26) Milgrom, F., Witebsky, E., Goldstein, R. and Loza, U. : J. Am. Med. Ass., $181: 476$ (1962). 